\title{
HUBUNGAN MEAN PLATELET VOLUME DENGAN HbA1C DAN PROFIL LIPID PADA PENDERITA DIABETES MELITUS
}

\author{
Rosdiana Mus ${ }^{1)}$, Yeremiah Rubin Camin²), Noortiningsih ${ }^{2)}$ \\ ${ }^{1}$ Prodi D III Teknologi Laboratorium Medis, Universitas MegaRezky Makassar, Indonesia \\ ${ }^{2}$ Jurusan Biomedik, Program Studi Biologi, Universitas Nasional, Indonesia \\ E-mail: rosdiana.mus@gmail.com
}

\begin{abstract}
Problems:The prevalence of Diabetes mellitus (DM) from year to year is increasing. DM is characterized by hyperglycemia and glucose intolerance that occurs because the pancreatic gland is not able to produce insulin in an adequate or because the body cannot use insulin produced effectively or both. In patients with DM, atherosclerosis accounted for almost $80 \%$ of all deaths. In patients with DM dysfunction occurs from platelets. Platelets play a role in the process of hemostasis and have important roles in atherosclerosis and arterial thrombosis. The Aim Of The Research:The average platelet Volume or known as Mean Platelet Volume (MPV) is the marker of function and the activation of platelets. This research aims to see the relationship between MPV and the lipid profile in patients with DM. Research Method: This research is a cross sectional research on medical record in the Rebo Market District general Hospital with samples of 300 patients. Data is obtained from January 2014 until December 2015. The Data was analyzed by using the help of SPSS 22.0 with double linear regression test methods. The Results:The resulting statistical test showed that there was no significant link between the MPV with lipid and pp glucose profiles $(\mathrm{P}>0.05)$ but there was a significant link between the MPV and the fasting glucose $(\mathrm{p}<0.05)$ in the DM sufferer.Conclusions:There is no relationship between MPV and cholesterol levels, LDL cholesterol levels, HDL cholesterol levels, triglyceride levels in people with diabetes. It was found that the relationship between MPV and HbAlc levels, fasting glucose levels and post prandial glucose levels in DM patients and MPV can be used as a marker of worsening of DM control.
\end{abstract}

Keywords: Atherosclerosis, Diabetes Mellitus, Platelet Mean Volume (MPV)

\begin{abstract}
ABSTRAK
Permasalahan:Prevalensi Diabetes Melitus (DM) dari tahun ke tahun semakin meningkat. DM adalah ditandai dengan hiperglikemia dan intoleransi glukosa yang terjadi karena kelenjar pankreas tidak dapat memproduksi insulin secara adekuat atau karena tubuh tidak dapat menggunakan insulin yang diproduksi secara efektif atau kedua-duanya. Pada penderita DM, aterosklerosis menyumbang hampir 80\% dari semua kematian. Pada penderita DM terjadi disfungsi dari trombosit. Trombosit berperan dalam proses hemostasis dan memiliki peran penting dalam aterosklerosis dan trombosis arteri.Rata-rata Volume trombosit atau dikenal dengan Mean Platelet Volume (MPV) adalah penanda fungsi dan aktivasi trombosit. Tujuan Penelitian:untuk melihat adanya hubungan antara MPV dengan HbA1C dan profil lipid pada penderita DM. Metode Penelitian:Penelitian ini merupakan penelitian cross sectional terhadap data rekam medik di Rumah Sakit Umum Daerah Pasar Rebo dengan sampel sebanyak 300 pasien.Data diperoleh dari bulan Januari 2014 sampai Desember 2015. Data dianalisis dengan menggunakan bantuan SPSS 22.0 dengan metode uji regresi linear ganda. Hasil: Uji statistik yang diperoleh menunjukkan tidak terdapat hubungan yang signifikan antara MPV dengan profil lipid dan glukosa pp $(\mathrm{p}>0,05)$ tetapi terdapat hubungan yang signifikan antara MPV dengan HbA1C dan glukosa puasa $(\mathrm{p}<0.05)$ pada penderita DM.Kesimpulan:Tidak terdapat hubungan MPV dengan kadar kolesterol, kadar kolesterol LDL, kadar kolesterol HDL, kadar trigliserida pada penderita DM. Ditemukanhubungan MPV dengan kadar HbA1c, kadar glukosa puasa dan kadar glukosa post prandial pada penderita DMsertaMPV dapat digunakan sebagai penandaperburukandari kontrol DM.
\end{abstract}

Kata Kunci:Aterosklerosis, Diabetes Melitus, Mean Platelet Volume (MPV) 


\section{PENDAHULUAN}

Secara global pada tahun 2013 DM telah membunuh 4,6 juta orang. Lebih dari $77 \%$ mengalami morbiditas dan $88 \%$ mengalami mortalitas dari jumlah penderita(IDF, 2013). Indonesia merupakan salah satu negara di benua Asia yang memiliki angka kejadian DM cukup tinggi. Hasil survei WHO pada tahun 2000 jumlah penderita DM di Indonesia adalah 8,4 juta jiwa, menempati urutan keempat setelah India (31,7 juta), Cina (20,8 juta), dan Amerika Serikat (17,7 juta), dan diperkirakan pada tahun 2030 prevalensi penyakit DM di Indonesia meningkat menjadi 21,3 juta jiwa (Shofiyah and Kusuma, 2014). Laporan Hasil Riset Kesehatan Dasar pada tahun 2013 yang dilakukan oleh Departemen Kesehatan menunjukkan prevalensi DM di Indonesia meningkat dari 1,1 \% (2007) menjadi 2,1 \% (2013) (Litbang, 2013).

Padapasien DM, aterosklerosis menyumbang hampir $80 \%$ dari semua kematian. Trombosit berperandalam proses hemostasis dan memiliki peran penting dalam aterosklerosis dan trombosisarteri. Ketika cedera vascular terjadi maka trombosit akan melekat pada endotel yang rusak untuk membentuk sumbat trombosit. Rata-rata volume trombosit atau dikenal dengan Mean Platelet Volume (MPV) adalah penanda fungsi dan aktivasi trombosit. Trombosit pada pasien DM akan mensintesis tromboksan dalam jumlah yang lebih besar dari trombosit yang normal. Hal ini ditemukan bahwa hiperglikemia menyebabkan trombosit lebih besar dan trombosit yang lebih besar juga melepaskan lebih banyak factor prothrombotik seperti tromboksan A2 (Ulutas et al., 2014). Selain itu, peningkatan jumlah dan ukuran trombosit mungkin mempengaruhi lebar distribusi trombosit dalam berkontribusi terhadap pathogenesis komplikasi vascular pada pasien DM. Hiper aktif trombosit memiliki peran penting dalam ini siasilesiaterosklerosis dan trombogenesis koroner(Jabeen et al., 2013). Studi kasus pasien DM dan non-DM telah mendokumentasikan hubungan yang signifikan antara MPV dengan DM 2, pra diabetes, obesitas dan factor risiko metabolic lainnya (Kilciler et al., 2010).

Tujuan penelitian ini untuk melakukan penelitian mengenai hubungan Mean Platelet Volume (MPV) dengan kadar HbA1c dan profil lipid pada penderita Diabetes Melitus.

\section{METODE PENELITIAN}

Penelitian ini merupakan studi observational dengan pendekatan cross sectional untuk mengetahui hubungan antara MPV dengankadar HbA1C padapenderita DM. Data yang digunakan adalah sekunder penderita DM selama periode Januari 2014 sampai dengan 
Desember 2015 dari RSUD Pasar Rebo Jakarta Timur. Subjek dalam penelitian ini yaitu pasien yang terdiagnosis DM yang dirawat di RSUD Pasar Rebo dengan kriteria inklusi penderita DM yang melakukan pemeriksaan MPV, profil lipid dan HbA1C.

Analisis data penelitian dikelompokkan berdasarkan usia, jenis kelamin, Nilai Mean Platelet Volume (MPV), kadar kolesterol total, kadar kolesterol HDL, Kadar kolesterol LDL dan kadar HbA1C, kadar glukosa puasa, kadar glukosa pp. Kemudian untuk mengetahui adanya hubungan dari variable tersebut, dilakukanan alisis data menggunakan ujiregresi linear ganda menggunakan SPSS 22.0.

\section{HASIL}

\section{Karakteristik dasar subjek penelitian}

Sebanyak 300 penderita yang terdiagnosis DM sebagai sampel yang diperoleh selama periode bulan Januari 2014 -Desember 2015 di Rumah Sakit Umum Daerah Pasar Rebo, diperoleh data pemeriksaaan Mean Platetelet Volume (MPV), HbA1C, profil lipid (kolesterol total, trigliserida, kolesterol HDL, kolesterol LDL), glukosa puasa dan glukosa pp dengan distribusi rata-rata dan simpangan baku dapat dilihat padaTabel 1.

Tabel1.Distribusi rata-rata dan simpangan baku parameter pemeriksaan

\begin{tabular}{lcc}
\hline Parameter Pemeriksaan & \multicolumn{2}{c}{ Deskrispi Variable (N=300) } \\
\cline { 2 - 3 } & Rata-rata & SD \\
\cline { 2 - 3 } MPV (fL) & 9,792 & 1,0453 \\
HbA1C (\%) & 7,727 & 1,885 \\
Kolesterol total (mg/dL) & 191,01 & 41,127 \\
Trigliserida (mg/dL) & 138,07 & 62,082 \\
Kolesterol HDL (mg/dL)) & 49,15 & 12,683 \\
Kolesterol LDL (mg/dL) & 115,69 & 35,875 \\
Glukosa Puasa (mg/dL) & 145,15 & 69,372 \\
Glukosa Post Prandial (mg/dL) & 209,69 & 109,37 \\
\hline
\end{tabular}

Berdasarkan tabel 1, dapat dilihat bahwa terdapat beberapa parameter yang mempunyai nilai ekstrim seperti pemeriksaan profil lipid (kolesterol total, trigliserida, kolesterol HDL, kolesterol LDL), glukosa puasa dan glukosa pp. Sedangkan untuk parameter MPV dan HbA1C memiliki nilai rata-rata dan standar deviasi yang cukup rendah dibandingkan dengan parameter yang lain.

\section{Hubungan Mean Platelet Volume dengan HbA1C dan profil lipid}

Untuk melihat adanya hubungan antara MPV dengan HbA1C, profil lipid, glukosa puasa dan glukosa pp penderita DM di bagi menjadi 2 (dua) group, yaitu Group A dengan nilai $\mathrm{HbA} 1 \mathrm{C} \leq 7 \%$ dan Group B dengan $\mathrm{HbA} 1 \mathrm{C}>7 \%$. Pengelompokan ini berdasarkan baik 
atau buruknya kontrol glukosa dari pasien DM, Group A sebagai penderita dengan DM yang terkontrol baik dan Group B sebagai penderita DM terkontrol buruk. Berdasarkan pengelompokan tersebut, ditunjukkan bahwa dari total 300 subjek penelitian, terdapat 125 subjek dengan kontrol glukosa yang baik dan 175 subjek dengan kontrol glukosa yang buruk. Hasil analisis regresi linear hubungan MPV dengan beberapa parameter pada penderita DM menunjukkan tidak terdapat hubungan yang signifikan antara MPV dengan profil lipid $(\mathrm{P}>0,05)$ baik untuk kolesterol total, trigliserida, HDL, LDL maupun glukosa pp. Hal ini menunjukkan bahwa peningkatan profil lipid dan glukosa pp pada penderita DM tidak mempengaruhi peningkatan nilai MPV sebagai penanda fungsi dan aktivasi trombosit. Profil lipid pada penderita DM mungkin hanya mempengaruhi jumlah trombosit tetapi tidak pada aktivasi trombosit, sedangkan pada penderita DM yang mengalami gangguan utama bukan pada jumlah trombosit tetapi pada aktivasinya. Apabila terjadi cedera jaringan karena stress oksidatif dan peradangan dan jumlah trombosit menurun, maka trombosit tetap diproduksi namun terjadi percepatan sehingga trombosit yang dihasilkan bersifat imatur dengan ukuran yang lebih besar dan lebih reaktif. Trombosit yang lebih besar dan reaktif akan mudah mengalami adhesi, aktivasi dan agregasi yang berperan terhadap komplikasi pada penderita DM. Binita Shah et al.,(2012) melaporkan bahwa tidak ada perbedaan yang signifikan nilai MPV pada subjek dengan sindrom metabolik dan menunjukkan bahwa hubungan sindrom metabolik terhadap peristiwa kardiovaskular mungkin tidak melalui mekanisme peningkatan aktivitas trombosit.

Gambar1. Boxplot hubungan MPV dan HbA1C Gambar2. Boxplot hubungan MPV dan GDP
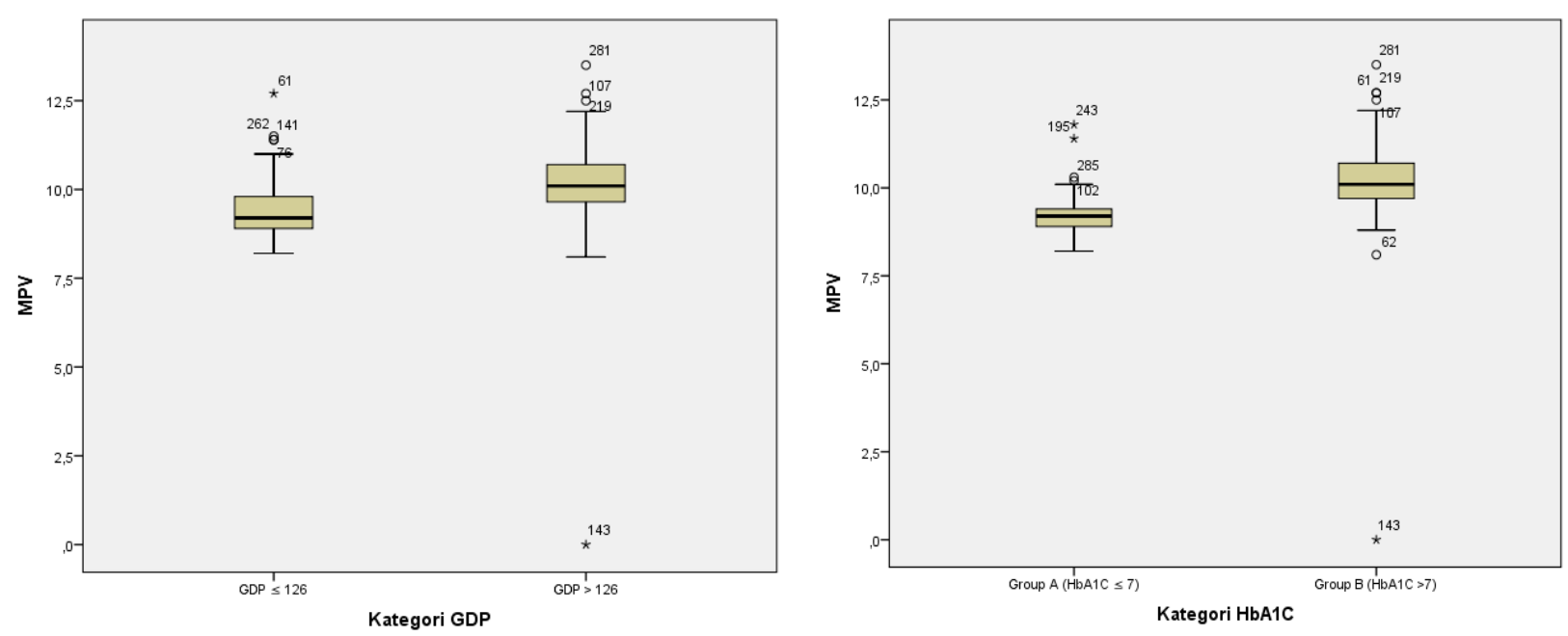
Pada penelitian ini ditemukan bahwa HbA1C (Gambar 1) dan glukosa puasa (Gambar 2) mempunyai hubungan yang signifikan dengan MPV dengan nilai $\mathrm{P}<0,05$. Hubungan tersebut dapat dilihat pada persamaan $\mathrm{MPV}=7,716+0,878 \mathrm{HbA1C}+0,002$ Glukosa puasa. Persamaan tersebut menunjukkan bahwa setiapkenaikan $1 \%$ nilaiHbA1Cmakaakan meningkatkan MPV sebesar 0,878 fLdan setiap kenaikan $1 \mathrm{mg} / \mathrm{dL}$ glukosa akan meningkatkan MPV sebesar 0,878 fLdan setiap kenaikan $1 \mathrm{mg} / \mathrm{dL}$ glukosa puasa akan meningkatkan MPV sebesar 0,002 fL.

Pada gambar sebaran boxplot di atas menunjukkan bahwa pada penderita DM dengan kontrol glukosa yang baik (Group A HbA1C $\leq 7 \%$ ) memiliki nilai rata-rata MPV yang lebih rendah dibandingkan dengan pasien DM dengan kontrol glukosa yang buruk (Group B HbA1C > 7\%). Pada group A garis median tidak berada di tengah dan terdapat data outlier di batas atas ekor yang artinya terdapat penderita DM yang memiliki nilai MPV lebih besar dari nilai tengah dan nilai rataan. Pada group B terdapat data outlier di batas atas ekor dan batas bawah ekor serta terdapat nilai ekstrim. Hal yang sama juga terlihat pada glukosa puasa dengan kadar glukosa puasa $\leq 126 \mathrm{mg} / \mathrm{dL}$ memiliki nilai rata-rata MPV lebih rendah dengan glukosa puasa $>126 \mathrm{mg} / \mathrm{dL}$. Pada group A terlihat tidak simetris karena batas atas ekor dan batas bawah ekor tidak sama panjang dan garis median tidak berada di tengah bagian kotak gambar. Pada group B median tidak berada di tengah dan terdapat nilai ekstrim. Pada kedua group terdapat data outlier di batas atas ekor yang artinya terdapat penderita DM yang memiliki nilai MPV lebih besar dari nilai tengah dan nilai rataan.

Hasil penelitian ini mempunyai kesamaan dengan penelitian yang dilakukan oleh Ulutas et al. (2014) yang menyatakan bahwa penderita DM mempunyai nilai MPV yang lebih tinggi dibandingkan dengan non-DM dan dengan uji korelasi pearson menunjukkan adanya hubungan yang signifikan dengan HbA1C dan glukosa puasa. Hal ini dapat menunjukkan bahwa peningkatan volume trombosit mungkin merupakan faktor penting dalam risiko peningkatan komplikasi vaskular pada penderita DM. Dalam hal ini, MPV dapat digunakan sebagai tes yang menguntungkan dalam pemantauan DM terkait aterosklerosis. Selain itu, Schneider (2009) juga menyatakan bahwa hiperglikemia dapat mengintensifkan aktivitas trombosit dengan meningkatkan produksi glikoprotein megakariositik.

Hal yang sama juga ditemukan oleh Min et al., (2015) yang menunjukkan bahwa terlihat hubungan yang signifikan antara MPV dengan HbA1C.Oleh karena itu, control glikemik yang baik dikaitkan dengan penurunan hiperaktivitas fungsi trombosit dan dengan demikian dapat mencegah atau menunda terjadinya kemungkinan komplikasi vascular pada DM . Penelitian Kadic et al., (2016) dengan metode cross sectional pada 117 penderita DM 
melaporkan bahwa pasien dengan kontrol glukosa yang baik ( $\mathrm{HbA} 1 \mathrm{C} \leq 7 \%)$ mempunyai nilai MPV yang lebih rendah dibandingkan dengan pasien dengan kontrol glukosa yang buruk $(\mathrm{HbA} 1 \mathrm{C}>7 \%)$. Penelitian tersebut juga menunjukkan adanya hubungan yang signifikan antara MPV dengan HbA1C dan glukosa puasa. Hal ini mengkonfirmasi bahwa aktivitas trombosit yang meningkat memiliki peran penting dalam pengembangan komplikasi vaskuler pada DM. Namun, Yenigun et al., (2014) dalam penelitiannya tidak menemukan hubungan antara MPV dan HbA1C, glukosa darah puasa, usia pasien, hipertensi, hiper lipidemia dan durasi DM. Akan tetapi menemukan adanya hubungan antara MPV dengan komplikasi makrovaskular. Penelitian lain Ozder and Eker, (2014) mengungkapkan bahwa MPV sebagai penanda fungsi dan aktivasi trombosit, secara signifikan lebih tinggi pada pasien dengan DM dibandingkan kontrol $(\mathrm{P}<0,05)$. Nilai MPV secara signifikan lebih tinggi pada pasien DM dengan tingkat $\mathrm{HbA} 1 \mathrm{C}>7,5 \%$ dibandingkan pada pasien dengan kadar $\mathrm{HbA} 1 \mathrm{C} \leq 7,5 \%$ $(\mathrm{p}<0,05)$. Hal ini menunjukkan HbA1Cdan MPV cenderung menurun pada kontrol glikemik yang baik. Oleh karenai tu, dapat disimpulkan bahwa control glikemik mempengaruhi fungsi dan aktivasi trombosit serta dapat mencegah atau menunda kemungkinan komplikasi vaskular.

\section{PEMBAHASAN}

Mean Platelet Volume (MPV) adalah penanda fungsi trombosit dan trombosit. Trombosit yang memiliki butiran padat lebih aktif secara biokimia, fungsional dan metabolik. Trombosit besar melepaskan lebih banyak tromboksan prothrombogenic A2, serotonin, betathromboglobulin dan membran prokoagulan protein seperti P-selectin dan glikoprotein. Trombosit akan mensekresi sejumlah besar zat mediator penting dari koagulasi, peradangan, trombosis dan aterosklerosis (Sarikaya et al., 2014).

Peningkatan aktivitas koagulasi pada penderita DM menyebabkan hiperkoagulasi yang ditandai dengan aktivasi trombosit yang bersifat kronik dan penurunan fibrinolisis. Trombosit memainkan peran secara integral dalam hubungan antara fungsi pembuluh darah dan trombosis, kelainan dalam biologis trombosit tidak hanya meningkatkan aterosklerosis tetapi juga mempengaruhi akibat dari gangguan plak dan aterotrombosis. Trombosit di dalam sel endotel akan menyerap glukosa yang tidak terkendali sebagai akibat dari kondisi hiperglikemia dan menghasilkan tekanan oksidatif. Akibatnya, agregrasi trombosit meningkat pada penderita DM. Perubahan-perubahan pada sel endotel akan menyebabkan produksi tissue factor (TF), substansi prokoagulan utama yang ditemukan di plak aterosklerosis, juga berhubungan dengan aktivasi dan agregasi trombosit (Puspita et al., 2015). Penelitian oleh 
Widiarto et al., (2013) menunjukkan bahwa pada penderita DM terjadi peningkatan trombosit meskipun tidak terdapat perbedaan yang signifikan antara penderita DM dengan komplikasi vaskular dan tanpa komplikasi vaskular. Peningkatan trombosit pada penderita DM disebabkan oleh peningkatan konsumsi perifer atau penggunaan trombosit karena pasien DM lebih mudah terjadi cedera vaskular karena proses stres oksidatif dan peradangan. Dapat juga diakibatkan karena waktu hidup trombosit menurun dan pergantian trombosit meningkat yang mengarah pada peningkatan regenerasi trombosit oleh megakariosit dan terjadi pelepasan trombosit baru yang hiperaktif ke dalam aliran darah.

Hiperaktivitas trombosit pada penderita DM dipengaruhi oleh beberapa hal seperti hiperglikemia yang merangsang protein kinase $\mathrm{C}$ sehingga menurunkan ambang rangsang trombosit. Trombosit pada penderita DM mengalami ketiadaan isyarat sehingga terjadi penurunan ambang rangsangannya. Trombosit pada penderita DM akan mengekspresikan Pselektin dan reseptor glikoprotein IIb/IIIa (GPIIb/IIIa) yang lebih banyak dan menyebabkan trombosit lebih peka terhadap rangsang rasa sangat nyeri, mengurangi jumlah dan mengganggu fungsi insulin. Insulin secara langsung mengatur fungsi trombosit melalui reseptor yang terkait dan terdapat di permukaannya. Insulin akan menghambat interaksi trombosit dengan kolagen dan menghambat respon agregasi trombosit (Enrica et al., 2014). Dalam penelitian ini, hasil menunjukkan bahwa pada penderita DM dengan kontrol glukosa yang buruk mempunyai nilai MPV yang lebih tinggi dibandingkan dengan kontrol glukosa yang baik dan ini dapat menjadi indikasi dari kontrol glikemik yang buruk. Ukuran trombosit yang meningkat mungkin salah satu faktor dalam peningkatan risiko aterosklerosis dikaitkan dengan DM dan terkait dengan komplikasi mikrovaskular dan makrovaskular. Oleh karena itu, MPV dapat digunakan sebagai penanda prognostik yang berguna untuk melihat risiko komplikasi kardiovaskular pada DM .

\section{KESIMPULAN}

Tidak terdapat hubungan MPV dengan kadar kolesterol, kadar kolesterol LDL, kadar kolesterol HDL, kadar trigliserida pada penderita DM. Ada hubungan MPV dengan kadar HbA1c, kadar glukosa puasa dan kadar glukosa post prandial pada penderita DMsertaMPV dapat digunakan sebagai penandaperburukandarikontrol DM. 


\section{DAFTAR PUSTAKA}

Binita Shah M, Ms, Daohang Sha P, Dawei Xie P, et al. 2012. The relationship between diabetes, metabolic syndrome, and platelet activity as measured by mean platelet volume. $\quad$ care.diabetesjournals.org $35:$ 10748https://www.ncbi.nlm.nih.gov/pmc/articles/PMC3329806/

Enrica M, Tristina N, Tjandrawati A. 2014. Rerata volume trombosit di Diabetes Melitus. Indonesian Journal Of Clinical pathology and Medical Laboratory 21 (1): 24-7https://ejournal.unair.ac.id/index.php/IJCPML/article/viewFile/1024/807

IDF. 2013. IDF Diabetes Atlas Sixth Edition. https://www.idf.org/sites/default/files/EN_6E_Atlas_Full_0.pdf

Jabeen F, Fawwad A, Rizvi HA, et al. 2013. Role of platelet indices, glycemic control and hscrp in pathogenesis of vascular complications in type-2 diabetic patients. Pak J Med Sci 29 (1) https://www.ncbi.nlm.nih.gov/pmc/articles/PMC3809177/

Kadic D, Hasic S, Spahic E. 2016. Mean Platelet Volume predicts the glycemic control deterioration in Diabetes Mellitus Type 2 patients. Med Glas (Zenica) 13 (1): 17https://pubmed.ncbi.nlm.nih.gov/26827701/

Kilciler G, Genc H, Tapan S, et al. 2010. Mean Platelet Volume and its relationship with carotid atherosclerosis in subjects with Non-Alcoholic Fatty Liver Disease. Upsala Journal of Medical Sciences (115): 2539https://www.ncbi.nlm.nih.gov/pmc/articles/PMC2971483/

Litbang. 2013. Riset Kesehatan Dasar. Jakartahttps://www.kemkes.go.id/resources/download/general/Hasil\%20Riskesdas\%20 2013.pdf

Ozder A, Eker HH. 2014. Investigation of Mean Platelet Volume in patients with type 2 Diabetes Mellitus and in subjects with impaired fasting glucose: A cost-effective tool in primary health care? Int J Clin Exp Med 7 (8): 22927https://pubmed.ncbi.nlm.nih.gov/25232423/

Puspita ND, Langi YA, Rotty LWA. 2015. Hubungan kadar trombosit dan kejadian kaki diabetik pada penderita Diabetes Melitus Tipe 2. Jurnal e-Clinic (eCl) 3 (1)https://ejournal.unsrat.ac.id/index.php/eclinic/article/view/7388

Sarikaya S, Sahin S, Akyol L, et al. 2014. Mean Platelet Volume is associated with myocardial perfusion defect in diabetic patients.Cardiovascular Journal Of Africa 25 (3): 110-3https://www.ncbi.nlm.nih.gov/pmc/articles/PMC4120130/

Schneider D. 2009. Factors contributing to in- creased platelet reactivity in people with diabetes. Diabetes Care 32: 525-7https://pubmed.ncbi.nlm.nih.gov/19336636/

Shofiyah S, Kusuma H. 2014. Hubungan antara pengetahuan dan dukungan keluarga terhadap kepatuhan penderita Diabetes Mellitus (DM) dalam penatalaksanaan di wilayah kerja Puskesmas Srondol Kecamatan Banyumanik Semarang. Prosding $\begin{array}{llllll}\text { Konferensi Nasional II PPNI Jawa Tengah } & 2014\end{array}$ https://jurnal.unimus.ac.id/index.php/psn12012010/article/view/1159

Ulutas KT, Dokuyucu R, Sefil2 F, et al. 2014. Evaluation of Mean Platelet Volume in patients with type 2 Diabetes Mellitus and blood glucose regulation: a marker for atherosclerosis?. Int J Clin Exp Med 7 (4) : 955-61 https://www.ncbi.nlm.nih.gov/pmc/articles/PMC4057846/

Widiarto NS, Posangi J, Mongan AE, et al. 2013. Perbandingan jumlah trombosit pada Diabetes Melitus Tipe 2 dengan komplikasi vaskular dan tanpa komplikasi vaskular di RSUP Prof. Dr. R. D. Kandou Manado. Jurnal e-Biomedik (eBM) 1 (1): 524 9https://ejournal.unsrat.ac.id/index.php/ebiomedik/article/view/4153 
Yenigun EC, Okyay GU, Pirpir A, et al. 2014. Increased Mean Platelet Volume In Type 2 Diabetes Mellitus. Dicle Medical Journal 41 (1): 17-

22https://www.researchgate.net/publication/299655824_Increased_mean_platelet_volu me in type 2 diabetes mellitus 